Agnieszka Watęga

Katedra Pedagogiki

Wydziat Nauk Pedagogicznych

UMK Toruń

\title{
Lwowskie studia Stanisława Kota - droga do doktoratu
}

\section{Uwagi wstępne}

Jak powszechnie wiadomo Stanisław Kot zaliczany jest nie tylko do grona twórców historii wychowania jako dyscypliny naukowej w Polsce, jest także określany mianem mistrza i kreatora „autentycznej szkoły naukowej”'. Jego osoba kojarzona jest przede wszystkim z Krakowem i działalnością na tamtejszej uczelni wyższej. Krakowski okres jego życia został już zresztą dość dokładnie opisany, głównie przez grono historyków związanych z Uniwersytetem Jagiellońskim ${ }^{2}$. W pracach tych przedstawiono kwestie aktywności uniwersyteckiej, dydaktycznej i wychowawczej Kota oraz stworzonej przez niego szkoły naukowej̉ Wielu autorów zwróciło uwagę na jego szczególną umiejętność na-

\footnotetext{
${ }^{1}$ K. Mrozowska, Twórcy historii wychowania jako dyscypliny naukowej, „Rozprawy z Dziejów Oświaty” 1989, T. XXXII, s. 107-123.

${ }^{2}$ Dokumenty znajdujące się w Archiwum Uniwersytetu Jagiellońskiego (dalej cyt. AUJ) m.in. sygn. WF II 121, Akta habilitacyjne S. Kota; sygn. S II 619, Akta osobowe S. Kota; sygn. Z 68/1; 69/ II; 70/ III, 71/ IV, Spuścizna Seminarium Historii Kultury; BJ- rkps. akc., Materiały S. Kota, sygn. Przyb. 1-178/83, umożliwiły bowiem dokładne odtworzenie faktów i opracowanie tych zagadnień: M.in.: H. Barycz, Stanisław Kot - historyk polskiego odrodzenia i reformacji, „Biuletyn Biblioteki Jagiellońskiej”, R. XXVIII, 1978, s. 5-20; idem, Stanisław Kot-życie i dzieło, w: S. Kot, Polska złotego wieku a Europa. Studia i szkice, wyboru dokonał, przygotował do druku i wstępem opatrzył H. Barycz, Warszawa 1987, s. 19-64; J. Dybiec, Stanisław Kot (1885-1975), w: Historia wychowania w XX wieku. Dorobek i perspektywy, red. T. Gumuła, J. Krasuski, S. Majewski, Kielce 1998, s. 65-75; J. Dybiec, Stanisław Kot (1885-1975), w: Złota Księga Wydziału Historycznego Uniwersytetu Jagiellońskiego, red. J. Dybiec, Kraków 2000, s. 260-270; A.K. Banach, Działalność uniwersytecka Stanisława Kota, w: Stanisław Kot - uczony i polityk. Pokłosie sesji naukowej, red. A. Fitowa, Kraków 2001, s. 191-198.

${ }^{3}$ Na ten temat także m.in. W. Szulakiewicz, Kierunki badań historyczno-oświatowych w szkole Stanisława Kota. Wybrane problemy, w: Stan i perspektywy historii wychowania, red. W. Jamrożek, Poznań 1995, s. 33-39; Z. Pietrzyk, Marek Wajsblum - ulubiony uczeń Stanisława Kota, w: Stanisław Kot - uczony i polityk...,
} 
wiązywania współpracy ze studentami - układano nawet na ten temat wierszowane strofy ${ }^{4}$. We współczesnym piśmiennictwie spotkać można stwierdzenia, że być uczniem Kota było samo przez się chluba ${ }^{5}$. Warto przytoczyć w tym miejscu opinię Andrzeja Kazimierza Banacha, który stwierdził, że prof. Kot należał do tej niezbyt często spotykanej kategorii uczonych, którzy potrafili łaczyć umiejętnie cechy wybitnego badacza, posiadajacego na swym koncie niezwykle wartościowy dorobek naukowy, z walorami wytrawnego pedagoga. Udało mu się skupić wokót siebie wyjątkowo zdolnych uczniów, których zauroczyt swoją wszechstronna umysłowościa i rozbudzit w nich zapał do pracy naukowej ${ }^{6}$. Rzeczywiście spośród jego studentów, głównie uczestników seminarium historii kultury, które prowadził przez szereg lat, kilku wybrało drogę kariery naukowej i trwale zaznaczyło swoją obecność w naukach humanistycznych ${ }^{7}$. W świetle powyższych opinii można stwierdzić, że został on powszechnie uznany za Mistrza, wybitnego nauczyciela i dydaktyka. Znani są jego najwybitniejsi uczniowie, a wiele informacji na temat wzajemnych relacjach między nimi a Profesorem zawiera zachowana w zbiorach Działu Rękopisów Biblioteki Jagiellońskiej korespondencja ${ }^{8}$.

Niewiele natomiast wiadomo o przebiegu jego studiów na Uniwersytecie we Lwowie, o jego kontaktach z poszczególnymi profesorami, a zatem o procesie kształtowania się samego Kota jako badacza. Jest to interesujące, ponieważ dość szybko po przybyciu do Krakowa jego dorobek twórczy, z okresu lwowskiego, został zauważony i doceniony przez członków Akademii Umiejętności. Należy zatem postawić pytanie o środowisko, które nie tylko go uformowało, ale też umożliwiło mu dalszy rozwój i szybką adaptację w tak szacownym naukowym gronie. W dotychczasowych opracowaniach brakuje bowiem dokładnych informacji na ten temat, nie możemy zatem na ich podstawie udzielić jednoznacznej odpowiedzi na pytania dotyczące jego studiów i spotkanych w tym czasie własnych Mistrzów. Kim byli i w jakim zakresie ukierunkowali nie tylko zainteresowania przyszłego autora podręcznika historii wychowania, ale być może także jego metody pracy jako wykładowcy akademickiego?

Powszechnie wiadomo jedynie, że Stanisław Kot w latach 1904-1910 studiował filologię polską i klasyczną, pedagogikę oraz prawo na Uniwersytecie we Lwowie ${ }^{9}$ O tej,

s. 213-224. Jego wkład w rozwój dydaktyki historii wychowania omawia m.in. W. Szulakiewicz, Historia oświaty $i$ wychowania w Polsce 1918-1939. Studium historiograficzne, Torun 2000, s. 180-183. Działalność polityczną Kota, z uwzględnieniem początków jego drogi naukowej, prezentuje natomiast T.P. Rutkowski, Stanistaw Kot 1885-1975. Biografia polityczna, Warszawa 2000.

${ }^{4}$ A.K. Banach, op. cit., s. 196. Np. „Ledwie zjawił się z kulturą / Już otoczon uczniów chmurą”.

${ }_{5}^{5}$ W. Urban, Badania nad reformacja w okresie II Rzeczypospolitej, w: Środowiska historyczne II Rzeczypospolitej, cz. II, Materialy konferencji naukowych w Cedzynie i Bialymstoku w 1986 i 1987, red. J. Maternicki, Warszawa 1987, s. 312, cyt za: Z. Pietrzyk, op. cit., s. 213.

${ }^{6}$ A.K. Banach, op. cit., s. 196.

7 Jak podaje J. Dybiec „Wychował Kot 22 doktorów, co w skali uniwersyteckiej [...] było znaczącą liczbą. Dziewięć osób spośród jego doktorów uzyskało w przyszłości stanowiska profesorów, dwie zdobyły docentury". J. Dybiec, Stanistaw Kot (1885-1975)..., s. 74.

${ }^{8}$ Biblioteka Jagiellońska (dalej cyt. BJ), rkps. akc., Materiały S. Kota, m.in. 145/83 listy Stanisława Bodniaka, 154/83 - listy Jana Hulewicza.

${ }_{9}^{9}$ Por. m.in. H. Barycz, Stanisław Kot - życie i dzieto..., s. 16-18; J. Draus, Stanistaw Kot - historyk kultury $i$ wychowania, „Roczniki Nauk Społecznych KUL”, Pedagogika, Księga pamiątkowa ku czci Pani 
wymagającej wypełnienia, luce wspominał w roku 1987 jeden z uczniów Kota, Henryk Barycz. Stwierdził on wówczas, że: Jak przebiegały w szczegółach studia Kota, jakie z nich wynióst korzyści, kto wptynąt na ostateczne ukształtowanie jego profilu umysłowego i naukowego - to z powodu braku już dzisiaj dokumentacji i przekazów pamiętnikarskich odtworzyć możemy tylko z pewnym prawdopodobieństwem i skazani jesteśmy jedynie na domysty i dopetnienia droga dedukcji ${ }^{10}$. Także Julian Dybiec w roku 1998 zauważył, że: Na temat studiów Kota we Lwowie brak jest pewnych wiadomości ${ }^{11}$.

Rzeczywiście nie dysponujemy przekazami pamiętnikarskimi dotyczącymi bezpośrednio tych zagadnień, bowiem osobiste wspomnienia Kota urywają się właśnie w momencie rozpoczynania przez niego studiów na uniwersytecie we Lwowie ${ }^{12}$. Sądząc po zawartych tam charakterystykach profesorów ${ }^{13}$ i kolegów gimnazjalnych można przypuszczać, że zapewne i swoim wykładowcom z uczelni poświęciłby on w dalszej części swoich wspomnień wiele miejsca. Być może wyjaśniłby również, którzy z nich wywarli największy wpływ na jego dalszą drogę naukową. Jednak badacz, który chciałby poznać bliżej ten etap jego życia ma do dyspozycji nie mniej cenne źródła archiwalne. Materiały dotyczące życia i działalności S. Kota są rozproszone i znajdują się w różnych archiwach i bibliotekach zarówno w Polsce, jak i poza jej granicami ${ }^{14}$. Te obejmujące okres jego studiów zachowały się przede wszystkim we Lwowie. Są to oficjalne akta tamtejszego uniwersytetu - katalogi studenckie oraz księgi protokołów egzaminów doktorskich ${ }^{15}$. Ich ważne uzupełnienie stanowią, znajdujące się obecnie w zbiorach Archiwum Uniwersytetu Jagiellońskiego w Krakowie, dokumenty Kota z okresu jego studiów prawniczych ${ }^{16}$. Analiza tych materiałów pozwala szczegółowo odtworzyć przebieg studiów uniwersyteckich

Profesor Teresy Kukołowicz, T. XXIV, z. 2, Lublin 1996 s. 336; J. Dybiec, Stanisław Kot, w: Złota księga ..., s. 260-261; T.P. Rutkowski, Stanisław Kot (1885-1975), Biografia polityczna..., s. 15, 21; M. Flisak, Kot Stanisław (1885-1975), w: Stownik biograficzny polskiej historii wychowania, red. A. Meissner, W. Szulakiewicz, Toruń 2008, s. 402.

${ }^{10}$ H. Barycz, Stanisław Kot-życie i dzieło..., s. 16.

11 J. Dybiec, Stanisław Kot (1885-1975), w: Historia wychowania w XX wieku..., s. 66.

12 Wspomnienia te opublikowano w 4 kolejnych numerach „Zeszytów Historycznych” wydawanych w Paryżu w latach 1967-1968 (z. XI, s. 95-122 - część poświęcona głównie dzieciństwu i początkowej edukacji; z. XII, s. 163-178 oraz z. XIII, s. 78-91 - wspomnienia z czasów gimnazjalnych, z. XIV, s. 123-149, różne wspomnienia, w tym także wzmianka o pierwszej podróży Kota do Włoch w roku 1925).

13 S. Kot, Wspomnienia, „Zeszyty Historyczne” z. XII/1967, s. 172-178.

14 Źródła te zestawił m.in. T.P. Rutkowski, Stanisław Kot 1885-1975. Biografia polityczna..., s. 6-7, $431-433$.

15 Derżawnyj Archiw Lwowskoj Obłasti - Państwowe Archiwum Obwodowe we Lwowie (dalej cyt. jako DALO), f. 26, Akta Uniwersytetu we Lwowie, op. 15, Katalogi studentów: spr. 611, semestr letni r. akad. 1904/1905, s. 102-103, nr 292; spr. 612 zimowe półrocze r. akad. 1904/1905, s. 115-116, nr 320: spr. 613 letnie półrocze r. akad. 1905/1906, s. 122-123, nr 283; spr. 614 zimowe półrocze r. akad. 1905/1906, s. 129-130, nr 314; spr. 615 zimowe półrocze r. akad. 1906/1907, s. 120-121, nr 295; spr. 616 letnie półrocze r. akad.1906/1907, s. 114-115, nr 271; spr. 617 Katalog główny słuchaczów zwyczajnych wydziału filozoficznego w c.k. Uniwersytecie lwowskim zapisanych w letniem półroczu roku akademickiego 1907/1908, s. 109-111, nr 245; spr. 618 zimowe półrocze r. akad. 1907/1908, s. 115-116, nr 270; spr. 726, Księga protokołów o złożenie egzaminów końcowych na dysertację doktorską, k. 305

${ }^{16}$ AUJ, Spuścizna Stanisława Kota (1885-1975), sygn. 70/1, Dokumenty i materiały osobiste S. Kota, Indeks wydany przez Uniwersytet Lwowski w roku 1908. 
Kota i ukazać jego drogę do wieńczącego je doktoratu. Dzięki tym źródłom możemy także wysnuć pewne wnioski dotyczące jego Mistrzów.

\section{Studia polonistyczne i mistrzowie Stanisława Kota}

Stanisław Kot nie od razu zdecydował się na studia w zakresie filologii polskiej i klasycznej. Jeszcze podczas nauki w gimnazjum myślał o prawie, ekonomii bądź socjologii. Jego ówcześni profesorowie zauważali jednak, że wykazywat szczególne zamiłowanie do nauki języka i literatury ojczystej ${ }^{17}$. Ostatecznego wyboru dokonał pod wpływem inspektora Rady Szkolnej Krajowej, Emanuela Dworskiego ${ }^{18}$, który podczas wizytacji zwrócił uwagę na jego uzdolnienia filologiczne ${ }^{19}$. Dlatego też po uzyskaniu matury, na której otrzymał niemal wyłącznie noty celujące, Kot rozpoczął studia w tym zakresie. Wybór uczelni we Lwowie tłumaczył po latach następująco: Lwów pociagał ruchliwościa, wartkim życiem, swobodą, przyjazna atmosfera zbiorowości i ulicy ${ }^{20}$.

Już od pierwszego roku swoich studiów regularnie uczęszczał na zajęcia prowadzone przez wybitnych znawców dziejów literatury polskiej Wilhelma Bruchnalskiego ${ }^{21}$ i Józefa Kallenbacha 22 (wśród jego wykładowców z I semestru odnajdujemy tylko ich nazwiska). Niektóre z nich kilkakrotnie zostały wpisane do planu jego zajęć. Przykładowo przez trzy semestry słuchał wykładów Bruchnalskiego o historii literatury polskiej w epoce odrodzenia oraz zgłębiał, pod jego kierunkiem, tajniki głosowni języka polskiego. Także na wy-

17 T. P. Rutkowski, Stanisław Kot 1885-1975 ..., s. 15.

18 Emanuel Dworski (1850-1916), pedagog, absolwent studiów w zakresie filologii klasycznej na Uniwersytecie Jagiellońskim w Krakowie, wieloletni nauczyciel języków klasycznych w szkołach średnich. Był kolejno inspektorem szkół ludowych okręgu jarosławskiego, krajowym inspektorem szkół ludowych i seminariów nauczycielskich Galicji Zachodniej, a w latach 1895-1916 inspektorem szkół średnich. Walczył o prawa języka i ludności polskiej na Bukowinie, był zwolennikiem gimnazjów klasycznych. Zdaniem Antoniego Knota „,należał do wybitniejszych pedagogów galicyjskich”. A. Knot, Emanuel Dworski, w: Polski słownik biograficzny, t. VI, Kraków 1948, s. 24-25.

19 H. Barycz, Stanistaw Kot-życie i dzieło..., s. 14.

20 S. Kot, Stanisław Estreicher na tle życia kulturalnego Krakowa, w: Straty kultury polskiej, t. II, Glasgow 1945, s. 3-4, cyt. za T.P. Rutkowski, Stanisław Kot 1885-1975 ..., s. 16.

${ }^{21}$ Wilhelm Bruchnalski (1859-1938), od roku 1900 docent historii literatury Uniwersytetu we Lwowie, wieloletni kierownik tamtejszej Katedry Historii Literatury Polskiej (1907-1931). Dziekan Wydziału Filozoficznego tej uczelni. Szerzej na ten temat: Biogramy uczonych polskich. Materiały o życiu i działalności członków AU w Krakowie, TNW, PAU, PAN, cz. I: Nauki społeczne, Z. 1: A-J, opr. A. Śródka. P. Szczawiński, Wrocław-Warszawa-Kraków-Gdańsk-Łódź 1983, s. 158-162; J. Starnawski, Wilhelm Bruchnalski (21 V 1859 - 6 XII 1938), w: idem, Sylwetki lwowskich historyków literatury, Łódź 1997, s. 75- 87.

22 Józef Kallenbach (1861-1929), wykładał historię literatury polskiej początkowo na Uniwersytecie Jagiellońskim, później także we Lwowie i w Wilnie. Był dziekanem Wydziału Filozoficznego Uniwersytetu Lwowskiego, rektorem Uniwersytetu Jagiellońskiego oraz przewodniczącym Komisji do Badań w Zakresie Historii Literatury i Oświaty w Polsce Akademii Umiejętności. Szerzej na ten temat: J. Spytkowski, Kallenbach Józef, w: Polski słownik biograficzny, t. 11, Wrocław-Warszawa-Kraków 1964-1965, s. 491-493; Biogramy uczonych polskich..., Cz. I, Z. 2: K-O, opr. A. Śródka, P. Szczawiński, Wrocław-Warszawa-Kraków-Gdańsk 1984, s. 28-32; J. Starnawski, Józef Kallenbach (24 XI 1861 - 12 XI 1929), w: idem, Sylwetki lwowskich historyków..., s. 66-74: J. Kleiner, Józef Kallenbach (1861-1929), w: Poloniści Uniwersytetu Jagiellońskiego, wyd. H. Markiewicz, Kraków 1998, s. 245-255. 
kłady Kallenbacha obejmujące tematykę rozkwitu romantyzmu w Polsce uczęszczał przez trzy semestry. Wiele godzin spędzał również na ich seminariach, szczególnie na seminarium historii literatury polskiej starszej Bruchnalskiego. Należy zaznaczyć, że bywał na nich także w okresie przygotowywania swojej rozprawy doktorskiej, zresztą to właśnie Kallenbach i Bruchnalski zostali jego recenzentami23. Te częste kontakty nie pozostały zapewne bez wpływu na kształtowanie się zainteresowań naukowych Kota, który zaliczany jest, wraz z innym historykiem wychowania Stanisławem Łempickim ${ }^{24}$, do grona ich najwybitniejszych uczniów ${ }^{25}$. W związku z niezbyt poprawnymi relacjami pomiędzy tymi dwoma uczonymi ${ }^{26} \mathrm{H}$. Barycz podkreślał, że zyskanie sobie przez Kota życzliwości oby$d w u$, należało do arcywyjątków ${ }^{27}$.

Kim zatem byli i jakie zainteresowania naukowe posiadali profesorowie odgrywający tak ważną rolę w edukacji przyszłego historyka wychowania? Wilhelm Bruchnalski bywa określany mianem „tytana wiedzy” oraz ,jednego z największych wśród historyków literatury polskiej”, który „nie zajmował się krytyką, odrzucał sferę sztuki, traktując swe badania wyłącznie jako naukę"28. Szczególnie interesowały go dzieje literatury polskiej z okresu od późnego średniowiecza aż do romantyzmu, historia i kultura XIX-wiecznej Galicji oraz epistolografia i edytorstwo ${ }^{29}$. Badał głównie związki polskiej kultury epoki średniowiecza $z$ europejskimi prądami tego okresu i wzajemne kontakty ludzi pióra ${ }^{30}$. Tych zagadnień dotyczyła m.in. jego rozprawa doktorska z 1885 r. pt. „Ślady wpływu literatury obcej na polską w XV i na początku XVI wieku”. Na uniwersytecie prowadził przede wszystkim wykłady z zakresu historii literatury polskiej. Jak podaje Jerzy Starnawski znaczna część wykładów [Bruchnalskiego - A.W.] poświęcona była poetyce dawnych wieków. Zakresowo niewiele wychodzit Bruchnalski, mimo swych badań mickiewiczowskich, poza literaturę dawnych wieków, czując się wyraźnie historykiem literatury

${ }^{23}$ DALO, f. 26, op. 15, spr. 611-618; Ibidem, spr. 726, k. 305; AUJ, Spuścizna Stanisława Kota (1885-1975), sygn. 70/1, Dokumenty i materiały osobiste S. Kota, Indeks wydany przez Uniwersytet Lwowski w roku 1908.

${ }^{24}$ Stanisław Łempicki (1886-1947) wieloletni kierownik Katedry Historii Szkolnictwa i Oświaty na Uniwersytecie we Lwowie, współtwórca pierwszych czasopism historyczno-oświatowych w Polsce, redaktor Encyklopedii wychowania, autor ponad 250 prac, w tym dotyczących m.in. polskich tradycji i ideałów wychowawczych. Szerzej na ten temat m.in.: J. Starnawski, Stanisław Łempicki, w: idem, Sylwetki lwowskich historyków..., s. 220-236; E. Brodacka-Adamowicz, Stanisław Łempicki (1886-1947) - człowiek i historyk, Toruń 2003; W. Szulakiewicz, Stanisław Łempicki (1886-1947), w: Złota księga historiografii lwowskiej, red. J. Maternicki przy współpracy L. Zaszkilniaka, Rzeszów 2000, s. 555-568 (tam dalsza bibliografia).

${ }^{25}$ Por. m.in. Biogramy uczonych polskich, cz. I, z. 2, s. 30-31; ibidem, cz. I, Z. 1, s. 161.

${ }^{26}$ Jak podaje J. Starnawski „Gdy w latach lwowskich [Kallenbach-A.W.] kolegował się z Bruchnalskim [...], który jako uczony Kallenbacha przewyższał, nie mogli przypaść sobie do gustu, bo byli do siebie niepodobni: Bruchnalski rejestrował potknięcia Kallenbacha, Kallenbach nie czuł potrzeby zaczepiania Bruchnalskiego". J. Starnawski, Wilhelm Bruchnalski..., w: idem, Sylwetki lwowskich historyków ..., s. 70. H. Barycz natomiast oceniał, że „spór między nimi był naprawdę homerycki”. H. Barycz, Stanisław Kot - życie i dzieto..., s. 17.

27 Ibidem.

28 J. Starnawski, Wilhelm Bruchnalski..., w: idem, Sylwetki lwowskich historyków..., s. 87.

29 Biogramy uczonych polskich..., cz. I, z. 1, s. 158.

${ }^{30}$ Ibidem, s. 160. 
staropolskiej ${ }^{31}$. Ponieważ jako badacz ,hołdował metodzie filologicznej; na seminariach uczył filologicznego myślenia: wymagał i od uczniów i od siebie analizy opartej na przemyśleniach podbudowanych warsztatowo"32.

Stanisław Kot miał możliwość przyswojenia sobie powyższych umiejętności w czasie studiów, uczestniczył bowiem już od III semestru w jego licznych seminariach ${ }^{33}$. Były to seminaria historii literatury polskiej, w tym literatury polskiej starszej i słowiańskiej oraz seminarium filologii polskiej. Doskonałym wprowadzeniem do tych zajęć były ćwiczenia Bruchnalskiego zatytułowane „Wstęp metodyczny do studiowania historii literatury polskiej” oraz „Wstęp do historii literatury polskiej” czy „Wstęp do studiowania historii literatury polskiej”. W. Bruchnalski przybliżał przyszłemu kierownikowi Katedry Historii Kultury także historię literatury i krytyki literackiej, w tym historię literatury rzymskiej za cesarstwa, historię literatury polskiej w wiekach średnich i w epoce odrodzenia oraz prozę polską epoki złotej. Kot uczestniczył także w jego zajęciach poświęconych egzegezie, jak to wówczas określano „zabytków” języka polskiego i „pomników” języka staropolskiego oraz analizie dzieł Mickiewicza. To jemu też zawdzięczał zapewne doskonałą znajomość ojczystego języka. Świadczy o tym jego systematyczny udział w takich zajęciach Bruchnalskiego, jak: gramatyka literatury i języka staropolskiego, deklinacje, głosownia oraz nauka form języka polskiego ${ }^{34}$. Należy podkreślić, że jeszcze w roku akademickim 1908/1909, a więc w okresie intensywnych prac nad dysertacją doktorską, Kot przez dwa semestry uczestniczył w seminariach literatury polskiej starszej Bruchnalskiego. Potwierdzają to złożone w jego indeksie podpisy lwowskiego historyka literatury ${ }^{35}$.

Drugim profesorem, z którym Kot stykał się najczęściej w czasie swoich studiów filologicznych był Józef Kallenbach, który szczególnie interesował się historią literatury polskiej okresu odrodzenia i romantyzmu, edytorstwem oraz bibliotekoznawstwem ${ }^{36}$. Często pisze się o nim jako o „naczelnym < mickiewiczologu $>$ jego pokolenia” natomiast zdecydowanie zapomniany i niedoceniany jest jego dorobek w zakresie literatury staropolskiej ${ }^{37}$. Tymczasem już jego praca doktorska, podobnie jak późniejszy wykład habilitacyjny poświęcone były twórczości Jana Kochanowskiego. Zajmował się także twórczością Mikołaja Reja, Simonidesa oraz zagadnieniami pobytu Polaków w XVI-wiecznej Bazylei i Kolonii ${ }^{38}$. Należy zaznaczyć, że to właśnie lata jego pracy na uczelni we Lwowie określane są w literaturze jako „najszczęśliwsze” w całej jego działalności dydaktycznej ${ }^{39}$. Wykładał wówczas „najczęściej epokami literaturę polską przedrozbiorową i romantyzm, nie wkra-

31 J. Starnawski, Wilhelm Bruchnalski..., w: idem, Sylwetki lwowskich historyków..., s. 80.

32 Ibidem, s. 81.

33 DALO, f. 26, op. 15, spr. 613-615, 617-619.

34 Ibidem, spr. 611-619.

35 AUJ, Spuścizna Stanisława Kota..., sygn. 70/1, Dokumenty i materiały osobiste..., Indeks wydany przez Uniwersytet Lwowski w roku 1908.

36 Biogramy uczonych polskich..., cz. I, z. 2, s. 28-30.

37 J. Starnawski, Józefa Kallenbacha próba syntezy literatury polskiej końca XVI i XVII wieku, w: idem, Z dziejów polskiej nauki o literaturze. Dwanaście rozpraw, Łowicz 2004, s. 158.

38 Ibidem, s. 159.

39 J. Starnawski, Józef Kallenbach..., w: idem, Sylwetki lwowskich historyków..., s. 67. 
czając jednak w średniowiecze i literaturę poromantyczną. Wykłady o literaturze romantycznej doprowadzał do wielkiej tradycyjnej trójcy włącznie" ${ }^{\text {40 }}$. Należy podkreślić, że Kallenbach zalecał swoim słuchaczom czytanie dzieł wszystkich pisarzy - nie tylko tych najwybitniejszych oraz „przeprowadzanie umiejętnej selekcji” wartościowej literatury dopiero po wnikliwej i szeroko zakrojonej lekturze wielu różnych prac. Jego wykłady miały charakter nowatorski, pierwszy bowiem tak szeroko uwzględnił w nich pisarzy mieszczańskich ${ }^{41}$.

Pod kierunkiem Kallenbacha Kot zdobył wiedzę o niemal wszystkich okresach historii literatury ojczystej. Poznał dzięki niemu zarówno polską poezję (zapisał się na zajęcia dotyczące „Poezji polskiej XVI wieku” oraz „Poezji polskiej w zarysie”), jak i prozę. To Kallenbach przybliżył mu twórczość Mikołaja Reja oraz polską literaturę doby humanizmu i reformacji. Kot słuchał też jego wykładów obejmujących piśmiennictwo polskie XVII i XVIII wieku (m.in. „Dzieje literatury za czasów Zygmunta III Wazy i za Sasów”) oraz epoki romantyzmu („Twórczość Zygmunta Krasińskiego”, „Poezja polska XIX w.”, „Rozkwit romantyzmu w Polsce”, „Historia literatury do roku 1830” oraz „Historia literatury polskiej po 1831 r.”). Uczestniczył też w jego ćwiczeniach z filologii polskiej, ćwiczeniach seminaryjnych oraz metodycznych ${ }^{42}$.

J. Starnawski, oceniając wykłady Kallenbacha docenił przede wszystkim ich rolę inspiracyjną. Jak pisał: „Wykłady były nadzwyczaj instruktywne i jasne; dzięki obfitym cytatom słuchacze poznawali w jakimś zarysie literaturę przeszło stuletniego okresu. Selekcja przeprowadzona została na ogół trafnie i umiejętnie; wykład uwypuklający dzieła wybitne i wyodrębniający je z ,tłumu” innych, objął poetów miernych i słabych także. Instruktywne były wskazówki bibliograficzne, stanowiące z jednej strony legitymację autora z przeoranej literatury przedmiotu, z drugiej - pożyteczne informatorium dla studentów o tym, gdzie i co na dany temat przeczytać"43. Zwrócił też uwagę na to, że Kallenbach wnikliwie badał tropy różnorodnych wpływów literac$\mathrm{kich}^{44}$. Jego wykłady mogły zatem stanowić niewątpliwą inspirację dla studenta zainteresowanego tego typu poszukiwaniami.

Pogłębieniu wiedzy i umiejętności warsztatowych Kota służyło z pewnością także uczestnictwo w licznych seminariach prowadzonych przez Kallenbacha. W katalogach studentów Uniwersytetu Lwowskiego z lat 1904-1908 odnajdujemy jego wpis na seminaria: „Historii literatury polskiej XVII w.”, „Historii literatury polskiej”, „Literatury polskiej oraz filologii polskiej nowożytnej" ${ }^{45}$. W roku akademickim 1908/1909,

40 Ibidem, s. 73.

41 J. Starnawski, Józefa Kallenbacha próba syntezy..., s. 161-162.

${ }^{42}$ DALO, f. 26, op. 15, spr. 611-618.

43 J. Starnawski, Józefa Kallenbacha próba syntezy literatury polskiej..., s. 169-170. Zachowały się bowiem notatki właśnie $\mathrm{z}$ tych wykładów, których w czasie studiów słuchał S. Kot, a zatem „Literatury polskiej za Zygmunta III” - wygłaszanych w półroczu zimowym roku akademickiego 1906/1907 oraz „Literatury polskiej XVII wieku” z półrocza letniego 1907 roku oraz półrocza zimowego roku 1908. Ibidem, s. 160.

44 Ibidem, s. 164. Przykładowo: „Passus o wychowaniu dzieci w Piotra Zbylutowskiego Rozmowie szlachcica polskiego z cudzoziemcem wydał się Kallenbachowi <jakby z wizerunku Reja przefrazowany>".

${ }^{45}$ DALO, f. 26, op. 15, spr. 615-618. 
w semestrze zimowym, a więc w okresie gdy Kot podjął studia prawnicze i jednocześnie przygotowywał rozprawę doktorską, pracował także na seminarium filologii polskiej Kallenbacha ${ }^{46}$.

Wśród wykładowców historii literatury, których Kot spotkał na uczelni we Lwowie dotychczas wymieniano jedynie Bruchnalskiego i Kallenbacha. Tymczasem jego wiedzę z zakresu filologii polskiej poszerzali także Konstanty Zygmunt Wojciechowski ${ }^{47}$, Bronisław Gubrynowicz ${ }^{48}$ oraz Edward Franciszek Porębowicz ${ }^{49}$. Warto zatem przybliżyć ich zainteresowania naukowe i odpowiedzieć na pytanie, który z nich i w jakim zakresie mógł wywrzeć wpływ na kształtowanie się Kota jako przyszłego badacza. Wojciechowski uważany jest za pioniera tekstologii w Polsce oraz znakomitego komparatystę. Jego rozprawa doktorska dotyczyła Kajetana Koźmiana, habilitował się w 1904 r. na podstawie pracy „Werter w Polsce" ${ }^{50}$. Szczególnie interesowały go dzieje polskiej powieści, historia pseudoklasycystycznej poezji oraz komparatystyka i dydaktyka języka polskiego. Jest on autorem około 140 prac, w tym m.in. związanych z tematyką prowadzonych przez niego wykładów dotyczących przewrotu w umysłowości i literaturze polskiej po roku 1863 oraz genezy i dalszych dziejów rozwoju powieści polskich ${ }^{51}$. W roku akademickim 1905/1906 (i później ponownie, w roku akademickim 1916/1917), wykładał „Przewrót w umysłowości i literaturze polskiej po roku 1863" (tekst wykładu został po latach opublikowany we Lwowie $)^{52}$. Kot słuchał jego prelekcji na ten temat oraz wykładów dotyczących głównych kierunkach rozwoju powieści polskich ${ }^{53}$. Pewną przesłanką pozwalającą przypuszczać

${ }^{46}$ AUJ, Spuścizna Stanisława Kota..., sygn. 70/1, Dokumenty i materiały osobiste..., Indeks Uniwersytetu Lwowskiego.

${ }^{47}$ Konstanty Zygmunt Wojciechowski (1872-1924), absolwent studiów w zakresie historii literatury, filologii klasycznej i historii na Uniwersytecie we Lwowie. Przez wiele lat uczył języka polskiego w gimnazjach. Od 1904 r. związany z Uniwersytetem Lwowskim jako wykładowca historii literatury. Od roku 1904 był docentem historii literatury Uniwersytetu we Lwowie, a w latach 1916-1921 kierownikiem tamtejszej Katedry Literatury Polskiej. Członek Komisji do Badań w Zakresie Historii Literatury i Oświaty w Polsce. Por. Biogramy uczonych polskich ..., cz. I, z. 3: P-Z, opr. A. Śródka, P. Szczawiński, Wrocław-Warszawa-Kraków-GdańskŁódź 1985, s. 529-531; J. Starnawski, Konstanty Wojciechowski (11 III 1872-16 VII 1924), w: idem, Sylwetki lwowskich historyków ..., s. 88-99.

48 Bronisław Gubrynowicz (1870-1933), w okresie II Rzeczypospolitej zawiązany z Uniwersytetem Warszawskim. W latach 1894-1920 pracownik (początkowo jako skryptor, później zaś kustosz) Zakładu Narodowego im. Ossolińskich we Lwowie. Por. P. Grzegorczyk, Gubrynowicz Bronisław, w: Polski słownik biograficzny, t. IX, Wrocław-Kraków-Warszawa 1960, s. 128-129: Biogramy uczonych polskich..., cz. I, z. 1, s. 439-441; J. Starnawski, Bronisław Gubrynowicz (2 X 1870-6 V 1933), w: idem, Sylwetki lwowskich historyków..., s. $104-105$

49 Edward Franciszek Porębowicz (1862-1937), absolwent studiów filologicznych na Uniwersytecie Jagiellońskim, odbył także liczne studia zagraniczne m.in. w Berlinie, Wiedniu, Florencji i w Paryżu. Zanim związał się z uczelnią we Lwowie (i został kierownikiem utworzonej tam Katedry Filologii Romańskiej) przez wiele lat pracował jako bibliotekarz w Krakowie oraz w Bibliotece Polskiej w Paryżu. W roku akad. 1925/1926 był rektorem uniwersytetu we Lwowie. Szerzej na ten temat: Biogramy uczonych polskich..., cz. I, z. 3: $P-Z$, s. 121-125; J. Starnawski, Edward Porębowicz (20 II 1862-24 VIII 1937), w: idem, Sylwetki lwowskich historyków..., s. 45-60.

${ }^{50}$ J. Starnawski, Konstanty Wojciechowski..., s. 88-89.

${ }^{51}$ Biogramy uczonych polskich..., cz. I, z. 3, s. 529-531.

52 J. Starnawski, Konstanty Wojciechowski..., s. 97.

${ }^{53}$ DALO, f. 26, op. 15, spr. 611, 613. 
o docenianiu przez Kota swojego uniwersyteckiego profesora jest fakt, że to właśnie Wojciechowski był jednym z najaktywniejszych współpracowników wydawanej przez niego, od roku 1919 w Krakowie, „Biblioteki Narodowej”54.

W ramach tego wydawnictwa Kot współpracował jeszcze z jednym ze swoich lwowskich profesorów, z docentem historii literatury, Bronisławem Gubrynowiczem (doktorat uzyskał na podstawie pracy „Kazimierz Brodziński, 1830-1835. Przyczynek do biografii i charakterystyki" "55, habilitował się w 1904 na podstawie pracy „Romans w Polsce za czasów Stanisława Augusta" ${ }^{56}$ ). Interesowała go historia literatury polskiego oświecenia i romantyzmu oraz edytorstwo. To dzięki niemu rozpoczęto prace nad monografiami poświęconymi polskim pisarzom ${ }^{57}$. We Lwowie Gubrynowicz wykładał w latach 1904/19051919/1920 dzieje powieści polskich w okresie od XVI do XVIII wieku, literaturę romantyczną oraz prowadził cykl wykładów i ćwiczeń poświęconych krytyce literackiej ${ }^{58}$. Kot zawdzięczał mu znajomość twórczości poetyckiej Juliusza Słowackiego ${ }^{59}$ oraz krytyki literackiej XIX w. ${ }^{60}$

W gronie lwowskich wykładowców historii literatury, których Kot spotkał w okresie swoich studiów nie zabrakło także E. F. Porębowicza. W roku 1897 otrzymał on docenturę w zakresie filologii romańskiej i rozpoczął we Lwowie wieloletnie wykłady z historii literatury. Interesował się komparatystyką, edytorstwem i krytyką literacką. Był znawcą średniowiecznej i renesansowej literatury hiszpańskiej i portugalskiej oraz autorem świetnych przekładów m.in. „Boskiej komedii” (przekład ten uznano za „kongenialny”) ${ }^{61}$. Zajmowała go także literatura polska, szczególnie doby baroku, to on właśnie zdefiniował i wprowadził ten termin do nauki o literaturze, oraz romantyzmu (twórczość A. Mickiewicza i Zygmunta Krasińskiego) ${ }^{62}$. W przedostatnim, VII semestrze swoich studiów Kot słuchał właśnie jego wykładów z historii polskiej literatury romantycznej ${ }^{63}$. Jak wynika z zachowanej korespondencji autora „Szkoły Lewartowskiej” cenił dorobek naukowy swego profesora. Pragnął bowiem zachęcić Porębowicza do współpracy przy opracowywaniu wyboru poezji Adama Morsztyna w ramach „Biblioteki Narodowej”64. Jednak we własnych pracach obejmujących okres staropolski nie wyróżniał Kot zdefiniowanej przez Porębowicza epoki baroku ${ }^{65}$.

\footnotetext{
54 J. Starnawski, Konstanty Wojciechowski... , s. 94-96.

55 J. Starnawski, Bronisław Gubrynowicz..., s. 100.

56 Ibidem, s. 104.

${ }^{57}$ Biogramy uczonych polskich..., cz. I, z. 1, s. 439-441; J. Starnawski, Bronisław Gubrynowicz ..., s. 104-105.

58 Ibidem, s. 102-103.

${ }^{59}$ DALO, f. 26, op. 15 , spr. 611.

60 Ibidem, spr. 615.

${ }^{61}$ Biogramy uczonych polskich..., cz. I, z. 3, s. 121-125.

62 J. Starnawski, Edward Porębowicz..., s. 53-55.

${ }^{63}$ DALO, f. 26, op. 15, spr. 618.

64 J. Starnawski, Edward Porębowicz..., s. 56-57.

${ }^{65}$ Por. H. Barycz, Stanisław Kot - historyk polskiego odrodzenia i reformacji..., s. 9.
} 
Swoją wiedzę filologiczną przyszły historyk reformacji poszerzał także na zajęciach języków starosłowiańskich u Jana Leciejewskiego ${ }^{66}$ (Gramatyka języków starosłowiańskich ${ }^{67}$ ) i Adama Antoniego Kryńskiego ${ }^{68}$ (Gramatyka języków starosłowiańskich oraz Objaśnienie zabytków języków starosłowiańskich ${ }^{69}$ ). Leciejewski z wykształcenia slawista, z zamiłowania etnograf, pracował na Uniwersytecie we Lwowie jako docent prywatny, wśród jego prac odnaleźć można także ślady zainteresowań historią polskiej myśli pedagogicznej. Świadczy o nich chociażby jego szkic pt. „Zapatrywania Mikołaja Reja na wychowanie" "70. Kryński natomiast należał do współinicjatorów Encyklopedii wychowawczej ${ }^{71}$. Będąc absolwentem studiów matematyczno-fizycznych oraz językoznawczych, historycznoliterackich i historycznych w Szkole Głównej Warszawskiej, nie miał żadnych formalnych stopni naukowych. Jednak od roku 1907 był profesorem nadzwyczajnym uniwersytetu we Lwowie i kierownikiem Katedry Filologii Słowiańskiej. Interesowała go historyczna gramatyka języka polskiego, filologia słowiańska, dialektologia, bibliografia, leksykografia, edytorstwo ${ }^{72}$.

H. Barycz zwrócił uwagę na wpływ, jaki na Kota wywarło dwóch lwowskich mistrzów w zakresie filologii polskiej. Wskazał przede wszystkim na „Bruchnalskiego, znakomitego znawcę literatury średniowiecznej i renesansowej, badacza [...] twórczości M. Reja" oraz Kallenbacha ,autora studiów nad J. Kochanowskim i Sz. Szymonowicem, a zwłaszcza cennej publikacji źródłowej dotyczącej stosunków tego ostatniego z humanistami zagranicznymi” " Zdaniem Barycza „Wydaje się, że narodziny Kota historyka kultury dokonaty się pod ręka Bruchnalskiego. Mógł on tu zaważyć i przez swa ścistość, erudycję,

${ }^{66}$ Jan Leciejewski (1854-1929), slawista, etnograf, studiował we Wrocławiu filologię słowiańską, klasyczną oraz porównawczą, w 1884 zdobył tam doktorat filozofii. Odbył też studia uzupełniające w Wiedniu zakończone habilitacją w zakresie filologii słowiańskiej. W 1889 przeniósł docenturę na Uniwersytet Lwowski, na którym wykładał jako docent prywatny. Przez wiele lat pracował także jako nauczyciel gimnazjalny. Członek przybrany Towarzystwa Naukowego we Lwowie (współpracował z Wydziałem Filologicznym). Por. „Sprawozdanie Towarzystwa Naukowego we Lwowie” R. 1, z. 1, Lwów 1921, s. 19, 56-57.

${ }^{67}$ DALO, f. 26, op. 15, spr. 612-614.

${ }^{68}$ Adam Antoni Kryński (1844-1932), przez wiele lat był nauczycielem języków klasycznych i języka francuskiego w warszawskich gimnazjach, prowadził też wykłady w tamtejszym Towarzystwie Kursów Naukowych. Oprócz pracy na Uniwersytecie we Lwowie wykładał także na Uniwersytecie Warszawskim. Por. S. Urbańczyk, Kryński Adam Antoni, w: Polski słownik biograficzny, t. XV, Wrocław-Warszawa-Kraków 1970, s. 465-467; Biogramy uczonych polskich..., cz. I, z. 2, s. 206-210.

${ }^{69}$ DALO, f. 26, op. 15, spr. 617.

${ }^{70}$ J. Leciejewski, Zapatrywania Mikołaja Reja na wychowanie, „Roczniki Towarzystwa Przyjaciół Nauk w Poznaniu", t. XXIV, Poznań 1897.

71 Encyklopedia wychowawcza - wydawana we Lwowie w latach 1881-1922/23. Łącznie ukazało się IX tomów tego wydawnictwa. W roku 1914 zawieszono jej wydawanie z powodu trudności finansowych i wybuchu I wojny światowej, wznowiono je dopiero w 1922 r. Opublikowano wówczas 7 zeszytów, do litery P włącznie. W ocenie Stefana Wołoszyna „składają się na nią [Encyklopedię wychowawcza - A.W.] na ogół obszerne artykuły, traktujące o rozmaitych zagadnieniach wychowawczych i zasłużonych dla wychowania i oświaty postaciach historycznych. Wiele z tych opracowań pozostało do dziś wartościowymi - o historycznym, a niekiedy unikalnym znaczeniu - rozprawami pedagogicznymi”. S. Wołoszyn, Nauki o wychowaniu w Polsce w XX wieku, próba syntetycznego zarysu na tle powszechnym, wyd. II poszerzone, Kielce 1998, s. 190 .

72 „Sprawozdanie Towarzystwa Naukowego we Lwowie”, R. 1, z. 1, Lwów 1921, s. 19, 56-57.

${ }^{73}$ H. Barycz, Stanisław Kot - historyk polskiego odrodzenia i reformacji..., s. 6. 
metodę, swe zainteresowania historyczno-kulturalne: mógt zachęcić uprawianiem dziedzin przez polonistyke niedocenianych $i$ uważanych za uboczne oraz mało znaczace, jak literatura folklorystyczna czy panegiryczna; przez podniesienie rangi przypisów dedykacyjnych i projekt zebrania ich $w$ jeden wielki całościowy codex epistolaris ${ }^{74}$. Jako mniej doniosły oceniał natomiast wpływ Kallenbacha: zachowawcy z przekonań, badacza operujacego starymi metodami i zajmujacego się głównie poezją romantyzmu, choć miat też na swym koncie kilka prac z epoki renesansu ${ }^{75}$.

W świetle zachowanej dokumentacji Uniwersytetu Lwowskiego opinia H. Barycza wydaje się być uzasadniona. Jej słuszność potwierdza fakt regularnego uczestniczenia Kota w seminarium Bruchnalskiego z zakresu literatury polskiej starszej w okresie bezpośrednio poprzedzającym złożenie dysertacji doktorskiej. Należy jednak zauważyć, że Kot nie zrezygnował wówczas także całkowicie z kontaktów z Kallenbachem. Nie można też wykluczyć wpływu poglądów Gubrynowicza, dotyczących konieczności przygotowania monografii dotyczących polskich pisarzy, na podjęcie przez Kota badań nad dziełem Andrzeja Frycza Modrzewskiego. Zatem, doceniając wpływ Bruchnalskiego, nie należy pomijać i nie dostrzegać możliwości inspirowania zdolnego studenta także przez innych jego wykładowców historii literatury.

\section{Studia w zakresie filologii klasycznej}

Drugim, obok filologii polskiej, obszarem studiów Kota była filologia klasyczna. Wiedzę w tym zakresie zdobywał on przede wszystkim pod kierunkiem Bronisława Ignacego Kruczkiewicza $^{76}$ oraz Stanisława Józefa Witkowskiego ${ }^{77}$. Kruczkiewicz był znawcą literatury polsko-łacińskiej, przez wiele lat prowadził krytyczne badania nad tekstami rzymskimi. Należy także zaznaczyć, że popierał on nawiązywanie i utrzymywanie ożywionych kontaktów z naukowcami europejskimi ${ }^{78}$. Kot regularnie, przez kilka semestrów, uczęszczał na jego proseminaria greckie oraz wykłady dotyczące dziejów literatury rzymskiej za cesarstwa oraz administracji państwa rzymskiego ${ }^{79}$. Witkowski natomiast był hellenistą, badaczem historii starożytnego Egiptu oraz literatury polsko-łacińskiej. Dopuszczał on używanie jedynie klasycznej łaciny i uchodził za niezwykle wymagającego profesora, który „tępił bezwzględnie wszelkie niedociągnięcia językowe" ${ }^{80}$. To zapewne jemu za-

${ }^{74}$ H. Barycz, Stanisław Kot-życie i dzieło..., s. 16.

75 Ibidem.

${ }^{76}$ Bronisław Ignacy Kruczkiewicz (1849-1918), wykładał latynistykę zarówno we Lwowie, jak i w Krakowie. Był wieloletnim dyrektorem Lwowskiej Komisji Egzaminacyjnej dla Nauczycieli oraz prezesem Towarzystwa Filologicznego we Lwowie. Por. Biogramy uczonych polskich ..., cz. I, z. 2, s. 204-205.

77 Stanisław Józef Witkowski (1866-1950), uczył języków starożytnych w gimnazjach, na uczelni we Lwowie wykładał hellenistykę i papirologię. Uważany jest za twórcę podstaw naukowych polskiej papirologii. Przez wiele lat był redaktorem czasopisma „Eos”. Por. Biogramy uczonych polskich ..., cz. I, z. 3, s. 521-524.

78 Ibidem, zeszyt 2..., s. 204-205.

79 DALO, f. 26, op. 15, spr. 611, 614, 616-617.

${ }^{80}$ Biogramy uczonych polskich..., cz. I, z. 3, s. 521-524. 
wdzięczał Kot doskonałą znajomość języka łacińskiego, uczestniczył bowiem systematycznie przez cały okres studiów w jego proseminariach łacińskich. Witkowski zapoznał go także z literaturą grecką epoki cesarstwa, historią tragedii greckiej i teatru, historią i oświatą hellenizmu oraz Symfonionem Platona. Na jego zajęciach doskonalił on także gramatykę grecką i dialekt joński ${ }^{81}$.

Już w okresie swoich studiów prawniczych, a zatem w roku akademickim 1908/1909 Kot zapisał się także na proseminarium łacińskie do Tadeusza Sinki, który „uchodził za fenomenalnego erudytę światowej miary" ${ }^{2}$. Miał on bowiem niezwykle szerokie zainteresowania naukowe. Zajmował się nie tylko hellenistyką, literaturą polsko-łacińską ale także leksykografią, komparatystyką czy edytorstwem. Badał także historię literatury polskiej doby odrodzenia, baroku i romantyzmu. Kontakt z wykładowcą tego formatu, zapewne odegrał pozytywną rolę w procesie intelektualnego kształtowania się Kota jako samodzielnego badacza.

Z pewnością doskonała znajomość języków i literatury klasycznej, wyniesiona z okresu studiów ułatwiła nie tylko podjęcie prac nad dysertacją doktorską. Stanowiła także solidną podstawę dla dalszych poszukiwań naukowych i znalazła odzwierciedlenie w publikacjach Kota. Wszechstronna wiedza na temat starożytności pozwoliła również na wnikliwe i szczegółowe przedstawienie zagadnień wychowania helleńskiego, greckorzymskiego i rzymskiego oraz klasycznej myśli pedagogicznej w opracowanych przez niego podręcznikach historii wychowania.

\section{Edukacja pod kierunkiem historyków lwowskich}

O ile materiały archiwalne potwierdzają przypuszczenia H. Barycza dotyczące studiów historyczno-literackich S. Kota, o tyle już w przypadku jego opinii o edukacji historycznej skłaniają do wprowadzenia pewnych korekt. W katalogach studentów Uniwersytetu Lwowskiego nie zachowało się bowiem formalne poświadczenie obecności Kota na wykładach historycznych Tadeusza Wojciechowskiego ${ }^{83}$ czy Szymona Askenazego ${ }^{84}$.

${ }^{81}$ DALO, f. 26, op. 15, spr. 611, 613-617.

${ }^{82}$ AUJ, Spuścizna Stanisława Kota..., sygn. 70/1, Dokumenty i materiały osobiste..., Indeks Uniwersytetu Lwowskiego. Tadeusz Sinko (1877-1966), absolwent Uniwersytetu Jagiellońskiego, studia uzupełniające odbył w Bonn, Berlinie, Monachium i Paryżu. Docent filologii klasycznej. Wieloletni kierownik Katedry Filologii Klasycznej na Uniwersytecie Jagiellońskim, po roku 1907 związany z uczelnią we Lwowie. Por. Biogramy uczonych polskich..., cz. I, z. 3, s. 256-260.

83 Tadeusz Wojciechowski (1838-1919), historyk, mediewista. Przez wiele lat pracował w bibliotekach Krakowa i Lwowa. Od roku 1883 profesor nadzwyczajny Uniwersytetu Lwowskiego, kierował tam Katedrą Historii Polski. Warsztat badawczy historyków proponował poszerzyć także o elementy socjologii czy historii sztuki i językoznawstwa. Por. M. Barański, Wojciechowski Tadeusz, w: Słownik historyków polskich, red. M. Prosińska-Jackl, Warszawa 1994, s. 56-561; K. Olejnik, Tadeusz Wojciechowski (1838-1919), w: Złota ksiegga historiografii lwowskiej XIX i XX wieku..., s. 201-214.

${ }^{84}$ Szymon Askenazy (1865-1935), historyk dziejów nowożytnych. W latach 1906-1917 kierował Katedrą Historii Nowożytnej Uniwersytetu Lwowskiego. Miał duże zasług w zakresie badań nad okresem porozbiorowym, szczególnie nad dziejami dyplomacji i stosunków międzynarodowych tego okresu. Ważnym elementem jego prac były metody porównawcze i biograficzne. Por. M. Wierzbicka, Askenazy Szymon, w: Stownik histo- 
H. Barycz domniemywał, że w czasie studiów mogli oni wywrzeć na niego pewien wpływ i zaliczał ich nawet do grona jego potencjalnych Mistrzów ${ }^{85}$. Nie można jednak jednoznacznie wykluczyć możliwości ich wspólnych kontaktów, mających miejsce poza oficjalnymi ramami zajęć uniwersyteckich. Dostępne źródła archiwalne pozwalają natomiast potwierdzić zdanie Barycza dotyczące Ludwika Finkla ${ }^{86}$ : Niemal za pewnik uznać też należy kontakty Kota z prof. Ludwikiem Finklem [...] trwajace aż do końca doczesnych dni tego historyka: świadczy o tym pomoc Kota $w$ dostarczeniu Finklowi materiałów do jego ostatniej pracy ${ }^{87}$. Barycz zaliczył zresztą Finkla, obok Bruchnalskiego i Kallenbacha, do grupy „trzech głównych mistrzów” Kota z okresu studiów ${ }^{88}$. W indeksie Kota, z okresu studiów prawniczych, odnajdujemy poświadczenie jego uczestnictwa zarówno w seminarium historycznym (przez cały rok akademicki 1908/1909), jak i w wykładach dotyczących historii monarchii austro-węgierskiej (w semestrze letnim r. akad. 1908/1909) prowadzonych właśnie przez Finkla ${ }^{89}$. Fakt ten ma istotne znaczenie, Finkel bowiem należał do grona historyków o bardzo szerokich zainteresowaniach naukowych. Obejmowały one także, co należy tutaj szczególnie podkreślić, zagadnienia historyczno-oświatowe, dotyczące gównie dziejów polskich uczelni wyższych we Lwowie oraz w Wilnie. Poruszał on także ważne kwestie dydaktyczne, zabierał bowiem głos na temat konieczności przygotowania nowych podręczników do nauczania historii, postulując m.in. uwzględnianie w nich także dziejów rozwoju kultury i oświaty ${ }^{90}$.

Materiały lwowskie pozwalają także stwierdzić, że jedynym, poza Finklem, historykiem, który w szerszym zakresie uczestniczył w formalnej edukacji uniwersyteckiej Kota (a o którym dotychczasowe źródła milczą) był mediewista Stanisław Zakrzewski ${ }^{91}$. Kot

ryków polskich..., s. 23-24; J. Maternicki, Szymon Askenazy (1865-1935), w: Złota księga historiografii lwowskiej..., s. 321-342.

${ }^{85}$ H. Barycz, Stanisław Kot-życie i dzieło..., s. 17-18. Barycz następująco uzasadniał swoje przypuszczenia: „Wprost trudno przypuścić, by nie skorzystał z okazji poznania Tadeusza Wojciechowskiego, bywania na jego wykładach (choć prelegentem był on nienadzwyczajnym). Jego książka Szkice historyczne jedenastego wieku ukazała się waśnie w 1904 r., roku wstawienia Kota na uniwersytet. Uczyniła ona autora popularnym [...] synonimem i symbolem naukowego postępu i śmiałości, toteż młodemu studentowi, liberałowi religijnemu i antyklerykałowi, musiała przypaść do smaku” (Ibidem, s. 17-18). „Nie byłoby także nieprawdopodobieństwem jakieś zbliżenie Kota do Szymona Askenazego, bożyszcza ówczesnych młodych historyków, zwłaszcza tych, którzy brali czynny udział w tajnych ruchach niepodległościowych" (Ibidem).

${ }^{86}$ Ludwik Finkel (1858-1930), historyk czasów nowożytnych oraz bibliograf. Przez wiele lat związany z Uniwersytetem Lwowskim, kierował tam katedrą historii austriackiej oraz katedrą historii nowożytnej. Twórca m.in. Bibliografii historii polskiej. Uważany przede wszystkim za „historyka ostatnich Jagiellonów”. Por. Polski słownik biograficzny, t. VI, Kraków 1948, s. 466-469; M. Wierzbicka, Finkel Ludwik, w: Słownik historyków polskich..., s. 133-134; A. Wałęga, Finkel Ludwik Michał Emanuel (1858-1930), w: Słownik biograficzny polskiej historii wychowania..., s. 230-235.; K. Błachowska, Ludwik Finkel (1858-1930), w: Złota księga historiografii lwowskiej..., s. 285- 308.

${ }^{87}$ H. Barycz, Stanisław Kot-życie i dzieło..., s. 18.

${ }^{88}$ Idem, Stanisław Kot - historyk polskiego odrodzenia i reformacji..., s. 6.

${ }^{89}$ AUJ, Spuścizna Stanisława Kota..., sygn. 70/1, Dokumenty i materiały osobiste..., Indeks S. Kota wydany przez Uniwersytet Lwowski w roku 1908.

${ }_{90}$ Szerzej na ten temat m.in: J. Centkowski, Ludwik Finkel jako dydaktyk historii, w: Wielokulturowe środowisko historyczne Lwowa w XIX i XX wieku, t. II, red. J. Maternicki i L. Zaszkilniak, Rzeszów 2004, s. 201-208.

91 Stanisław Zakrzewski (1873-1936), przez 30 lat kierował Katedrą Historii Polski na Uniwersytecie we Lwowie, wieloletni prezes Towarzystwa Historycznego we Lwowie, a później Polskiego Towarzystwa Histo- 
słuchał jego prelekcji dotyczących doby piastowskiej oraz zarysu dziejów Polski, uczestniczył także w zajęciach z polskiej paleografii ${ }^{92}$. Zakrzewski uznawany był za znawcę politycznej historii Polski na przestrzeni X-XIII w., historii Kościoła oraz historiozofii. W latach 1906-1926 wykładał historię średniowiecznej Polski na Uniwersytecie we Lwowie. W literaturze spotkać można opinie, że ,jego wykłady uchodziły za trudne z powodu szkicowego sposobu omawiania poszczególnych problemów, często pozostających ze sobą w luźnym związku: wg uczniów i współpracowników uchodził za niezwykle wymagającego" ${ }^{93}$. Kot słuchał także wykładu historyka Bronisława Dembińskiego ${ }^{94}$ o teorii politycznej świata starożytnego ${ }^{95}$.

Zakres studiów historycznych S. Kota nie był zatem, przynajmniej w zakresie formalnym, tak szeroki jak dotychczas przypuszczano. Nie sposób jednak nie docenić znaczenia kontaktów przyszłego badacza reformacji z L. Finklem. Mógł on wpłynąć nie tylko na skrystalizowanie się zainteresowań Kota epoką odrodzenia, lecz także zainspirować go do podejmowania badań w zakresie historii wychowania, w tym do pracy nad podręcznikami do nauczania tego przedmiotu. Jego wpływ na ukierunkowanie czy ugruntowanie planów badawczych przyszłego historyka kultury miał tym istotniejsze znaczenie, że w tym okresie Kot był już wszechstronnie wykształcony w zakresie dziejów literatury i z pewnością otwarty na nowe inspiracje intelektualne.

\section{Studia pod kierunkiem lwowskich reprezentantów nauk o wychowaniu}

Studia Stanisława Kota przypadły na początkowy okres rozwoju nauk o wychowaniu, a wśród nich także historii wychowania, na Uniwersytecie Lwowskim ${ }^{96}$. Do grona współtwórców tamtejszej pedagogiki powszechnie zalicza się Bolesława Mańkowskiego ${ }^{97}$, któ-

rycznego, członek czynny Polskiej Akademii Umiejętności. Por. Biogramy uczonych polskich..., cz. I, z. 3, s. 567-570; M. Wierzbicka, Zakrzewski Stanisław, w: Stownik historyków polskich..., s. 571-572; K. Błachowska, Stanisław Zakrzewski (1873-1936), w: Złota księga historiografii lwowskiej..., s. 379-398.

92 DALO, f. 26, op. 15, spr. 613, 615.

93 Biogramy uczonych polskich..., cz. I, z. 3, s. 570.

${ }^{94}$ Bronisław Dembiński (1858-1939), od roku 1886 docent historii powszechnej Uniwersytetu Jagiellońskiego, prowadził w Krakowie do roku 1892 wykłady z nowożytnej historii powszechnej. Po roku 1892 związał się z Uniwersytetem we Lwowie (do roku 1916). Później pracował na uniwersytetach w Warszawie oraz w Poznaniu. Por. Biogramy uczonych polskich..., cz. I, z. 1, s. 283-287; M. Wierzbicka, Dembiński Bronisław, w: Słownik historyków polskich..., s. 105-106; T. Pawelec, Bronisław Dembiński (1858-1939), w: Złota księga historiografii lwowskiej..., s. 269-284.

95 DALO, f. 26, op. 15, spr. 617-618.

$96 \mathrm{Na}$ ten temat m.in. J. Chodakowska, Nauki pedagogiczne $w$ polskich uniwersytetach na przełomie XIX i XX wieku, „Kwartalnik Historii Nauki i Techniki” 1991, nr 2, s. 21-37; B. Luczyńska, Początki pedagogiki jako dyscypliny akademickiej na Uniwersytetach Jagiellońskim i Lwowskim w dobie autonomii, w: Galicja i jej dziedzictwo, t. 8, Myśl edukacyjna w Galicji 1772-1918. Ciagłość i zmiana, red. C. Majorek i A. Meissner, Rzeszów 1996, s. 34-42.

97 Bolesław Mańkowski (1852-1921) absolwent studiów filozoficznych i pedagogicznych we Lwowie, oraz studiów uzupełniających na uniwersytetach niemieckich. Przez wiele lat pracował w lwowskiej Bibliotece Uniwersyteckiej. W 1903 r. uzyskał veniam legendi w zakresie pedagogiki na uniwersytecie we Lwowie. Wieloletni redaktor czasopisma „Muzeum”. Por. J. Hulewicz, Mańkowski Bolesław, w: Polski słownik biograficz- 
ry otrzymał staranne przygotowanie do prowadzenia badań w zakresie tej dyscypliny. Tak sam pisał na ten temat w przedmowie do swojej pierwszej opublikowanej pracy „Szczególną zaś wdzięczność wyrażam czcigodnemu prof. Dr. Euzebiuszowi Czerkawskiemu ${ }^{98}$, ile, że On pierwszy zachęcił mnie i dał podstawę do samodzielnych badań w dziedzinie umiejętności filozoficznej. Wreszcie czuję obowiązek oddania dziękczynnego hołdu prof. filozofii na uniwersytecie lipskim Dr. med. i fil. W. Wundtowi ${ }^{99}$, któremu w mych studiach psychologicznych nadzwyczaj wiele jestem winien, jako też Dr. T. Zillerowi ${ }^{100}$, prof. pedagogiki, w którego seminarium pedagogicznym pobyt, miłem mi zawsze będzie wspomnieniem" ${ }^{101}$. Niezwykle szerokie i różnorodne zainteresowania naukowe Mańkowskiego obejmowały zarówno pedagogikę ogólną, psychologię i dydaktykę, jak i zagadnienia organizacji szkół i teorii pedagogicznej ${ }^{102}$. Jego prace pedagogiczne, dotyczące przede wszystkim aktualnych problemów szkolnictwa średniego, w ocenie Jana Hulewicza „są ważne jako materiał dokumentacyjny dla historii szkolnictwa galicyjskiego przełomu XIX i XX wieku”103. Ów ,prekursor i nauczyciel pedagogiki akademickiej”"104 w roku 1903 rozpoczął we Lwowie wykłady z zakresu pedagogiki oraz historii oświaty i wychowania, a cztery lata później objął kierownictwo utworzonego tam Seminarium Pedagogicznego. Prezentowane w literaturze statystyki z tego okresu wymownie świadczą o zainteresowaniu studentów lwowskich studiami pedagogicznymi. Seminarium przyciągało rzesze osób, w pierwszym roku jego funkcjonowania było ich 96, rok później już 149, a po dwóch latach aż $177^{105}$. S. Kot natychmiast zapisał się w poczet jego uczestników - już w letnim półroczu roku akademickiego 1907/1908 ${ }^{106}$. Jednak Mańkowskiego poznał znacznie wcześniej. W czasie czwartego i piątego semestru studiów, czyli w latach 1906-1907, brał udział w jego zajęciach z pedagogiki (w tym także w ćwiczeniach pedagogicznych) oraz z psychologii nauczania ${ }^{107}$.

ny, t. XIX, Wrocław-Warszawa-Kraków-Gdańsk 1974, s. 514-516. Szerzej na temat B. Mańkowskiego i jego seminarium pedagogicznego pisze m.in. K. Szmyd, Twórcy nauk o wychowaniu w środowisku akademickim Lwowa (1860-1939), Rzeszów 2003, s. 143-160.

${ }_{98}$ Euzebiusz Czerkawski (1822-1896), profesor filozofii i pedagogiki na Uniwersytecie we Lwowie, rzecznik powołania na tej uczelni samodzielnej Katedry Pedagogiki i umocnienia pozycji pedagogiki jako dyscypliny akademickiej. Współinicjator utworzenia Rady Szkolnej Krajowej. Szerzej na temat E. Czerkawskiego i jego poglądów pedagogicznych m.in. K. Szmyd, op. cit., s. 99-112.

99 Wilhelm Wundt (1832-1920), niemiecki filozof, psycholog i fizjolog. Profesor Uniwersytetu w Heidelbergu i w Lipsku. Założyciel pierwszego laboratorium psychologii eksperymentalnej. Por. W. Okoń, Nowy słownik pedagogiczny, wyd. IV, Warszawa 2004, s. 462.

100 Tuiskon Ziller (1817-1882), niemiecki pedagog, zwolennik herbartyzmu, profesor uniwersytetu w Lip$\mathrm{sku}$ - prowadził tam seminarium pedagogiczne dla kandydatów na nauczycieli. W roku $1868 \mathrm{z}$ jego inicjatywy powstało Towarzystwo Pedagogiki Naukowej. Por. W. Okoń, Nowy słownik pedagogiczny..., s. 482.

101 B. Mańkowski, O psychicznych zboczeniach fantazji. Szkic psychologiczno-pedagogiczny, Lwów 1880, s. 8 .

102 K. Szmyd, op.cit., s. 149.

103 J. Hulewicz, op. cit., s. 516.

104 K. Szmyd, op. cit., s. 143.

105 B. Łuczyńska, op. cit., s. 42.

106 DALO, f.26, op. 15, spr. 617.

107 Ibidem, spr. 613, 615. 
Spotkanie z Mańkowskim można uznać za znaczące dla ukształtowania się u Kota późniejszych zainteresowań historią oświaty. To na jego seminarium pedagogiczne przygotował on referat dotyczący Andrzeja Frycza Modrzewskiego jako teoretyka wychowania $^{108}$. Zgodnie bowiem ze statutem Seminarium opracowanym przez Mańkowskiego jego uczestnicy zobowiązani byli do przygotowywania samodzielnych referatów oraz recenzji ${ }^{109}$. To jemu zawdzięczał także druk swoich pierwszych rozpraw naukowych, które ukazały się na łamach czasopisma „Muzeum”110. Nie należy bowiem zapominać, że to właśnie Mańkowski zapoczątkował, jako redaktor tego pisma, wydawanie w tzw. dodatkach do „Muzeum” prac z zakresu dydaktyki i historii szkolnictwa w Polsce ${ }^{111}$. W dotychczasowej literaturze spotkać można opinie doceniające wagę kontaktów Kota z Mańkowskim, który „torował drogę nowoczesnym ideom pedagogicznym opartym na psychologii oraz historii wychowania, był gorącym orędownikiem i szermierzem reformy gimnazjów galicyjskich w nowym duchu oraz ich unarodowienia" "112. Warto także zaznaczyć, że Mańkowski przyjmował na swoje seminarium studentów różnych narodowości ${ }^{113}$ i sporządzał szczegółowe notatki dotyczące postępów każdego z nich ${ }^{114}$. Ten zwyczaj miał także później S. Kot ${ }^{115}$.

Studiując nauki pedagogiczne Kot poznał także wybitnego filozofa i pedagoga Kazimierza Twardowskiego ${ }^{116}$, który wykładał we Lwowie psychologię ogólną i eksperymentalną, dydaktykę, historię oraz teorię wychowania. Wspierał on również działania Mańkowskiego w kierunku powołania Seminarium Pedagogicznego ${ }^{117}$. Jego wykłady z psychologii, na które, jak wynika z uniwersyteckich katalogów studentów, uczęszczał

${ }^{108}$ H. Barycz, Stanisław Kot - historyk polskiego odrodzenia i reformacji..., s. 9.

109 K. Szmyd, op.cit., s. 154-155.

${ }^{110}$ H. Barycz, Stanisław Kot - historyk polskiego odrodzenia i reformacji..., s. 9; J. Draus, op. cit., s. 337.

111 J. Hulewicz, op. cit., s. 515.

112 H. Barycz, Stanisław Kot - zycie i dzieło..., s. 17.

113 Szmyd, op. cit., s. 158.

114 Ibidem, s. 159.

115 BJ, rkps. akc., Materiały Stanisława Kota, sygn. 117/83, Działalność dydaktyczna. Seminarium historii kultury i wychowania.

116 Kazimierz Twardowski (1866-1938) doktorat i habilitację w zakresie filozofii uzyskał na uniwersytecie w Wiedniu, wieloletni kierownik Katedry Filozofii na Uniwersytecie we Lwowie, dziekan Wydziału Filozoficznego i rektor tej uczelni w latach 1914-1917). Twórca „lwowsko-warszawskiej” szkoły filozoficznej.

Szerzej na temat K. Twardowskiego m.in. R. Jadczak, Kazimierz Twardowski. Twórca szkoły lwowskowarszawskiej, Toruń 1991; W. Okoń, Wizerunki wybitnych pedagogów polskich, Warszawa 2000, s. 447-470; K. Szmyd, op. cit., s. 168-179; W. Szulakiewicz, Działalność oświatowa i myśl pedagogiczna Kazimierza Twardowskiego, w: Historyczne źródła wybranych ofert edukacyjnych w Polsce współczesnej, red. D. Drynda, D. Ekiert-Grabowska, W. Łuszczuk, Katowice 1996, s. 27-35; Eadem, Działalność wychowawcza szkoły ludowej w ujęciu Kazimierza Twardowskiego, w: Chłopi-Naród-Kultura, t. 4, Kultura i oświata wsi, red. A. Meissner, Rzeszów 1996, s. 195-201; eadem, Istota i zakres dydaktyki ogólnej w Szkole Kazimierza Twardowskiego (Kazimierz Twardowski-Kazimierz Sośnicki-Bogdan Nawroczyński), w: Inspiracje dla współczesnej edukacji w dydaktyce Drugiej Rzeczypospolitej, red. D. Drynda, Katowice 2000, s. 22-34.

Bogdan Nawroczyński pisał o nim, że był „może jeszcze większym pedagogiem” niż filozofem. Por. W. Okoń, Wizerunki wybitnych pedagogów...., s. 447.

117 K. Szmyd, op. cit., s. 174. 
także regularnie S. Kot ${ }^{118}$, cieszyły się ogromną popularnością ${ }^{119}$. Przyszły historyk wychowania słuchał ponadto jego prelekcji z dziedziny filozofii i etyki ${ }^{120}$. Uczniowie Twardowskiego porównywali te wykłady do nabożeństwa ,podczas którego wszyscy w skupieniu słuchali jasnych słów o trudnych rzeczach” i „,propedeutyki dla wszystkich, którzy mieliby potem kogokolwiek czegokolwiek nauczać"121. Został on nawet określany mianem „nauczyciela uczonych”"122, który, jak stwierdza Wincenty Okoń, przyzwyczajat studentów do stosowania wobec siebie wysokich wymagań co do jakości wykonywanych prac oraz dyscypliny wewnętrznej i zewnętrznej ${ }^{123}$. W ocenie Władysławy Szulakiewicz Twardowski realizował w praktyce ,wiele postulatów z zakresu dydaktyki szkoły wyższej, można nawet stwierdzić, iż wypracował pewne metody i formy pracy stosowane w szkolnictwie akademickim" ${ }^{24}$. Wiele uwagi przywiązywał choćby do niezwykle starannego przygotowywania swoich wykładów ${ }^{125}$, co charakteryzowało w późniejszym okresie także działalność S. Kota. Świadczą o tym wymownie jego liczne zachowane w rękopisach konspekty i notatki do prowadzonych na Uniwersytecie Jagiellońskim zajęć ${ }^{126}$.

Zatem do grona Mistrzów Stanisława Kota z okresu studiów zaliczyć możemy obok Bruchnalskiego, Kallenbacha i Finkla także Mańkowskiego. O zakresie i znaczeniu ich wpływów na kształtowanie się zainteresowań badawczych Kota nie sposób formułować jednoznacznych ocen. Można przychylić się do zdania H. Barycza, że: Mimo [...] tylu mistrzów Kot chodził właściwie własnymi drogami. Był zbyt samodzielnym umysłem, nieskorym do poruszania sie po cudzych koleinach. Sam sobie wyszukiwat tematy, badat te epoki, które mu odpowiadały ${ }^{127}$. Nie należy jednak zapominać o tych, którzy umożliwili mu wszechstronny rozwój i ukształtowali jego „samodzielny umysł”. I chociaż bez wątpienia Kot nie poruszat się po cudzych koleinach to jego uniwersyteccy Mistrzowie z pewnością mieli znaczny udział we wskazaniu mu różnorodnych i interesujących dróg dalszego rozwoju. Jego wieloletnia dalsza współpraca z większością z nich zdaje się to potwierdzać. Trzeba także podkreślić, że to właśnie lwowscy Mistrzowie Kota umożliwili mu nawiązanie wieloletniej i niezwykle owocnej współpracy z profesorem Uniwersytetu Jagiellońskiego Stanisławem Estreicherem ${ }^{128}$.

118 DALO, f. 26, op. 15, spr. 617-618.

119 O tym, że wciąż szukano większych sal, które mogłyby pomieścić wszystkich studentów na wykładach Twardowskiego oraz o niemożności przyjęcia na jego seminaria wszystkich zgłaszających się kandydatów wspominają m.in. B. Łuczyńska, op. cit., s. 41; W. Okoń, Wizerunki sławnych pedagogów polskich ..., S. 450 .

120 DALO, f. 26, op. 15, spr. 613-614.

121 W. Szulakiewicz, Działalność oświatowa i myśl pedagogiczna Kazimierza Twardowskiego..., s. 32.

122 Por. W. Okoń, Wizerunki sławnych pedagogów polskich..., s. 447.

123 Ibidem, s. 452.

124 W. Szulakiewicz, Działalność oświatowa i myśl pedagogiczna Kazimierza Twardowskiego..., s. 31.

125 W. Okoń, Wizerunki sławnych pedagogów polskich..., s. 452.

${ }^{126}$ BJ rkps. akc., Materiały Stanisława Kota - m.in. Przyb. 12/83 konspekty do dziejów szkolnictwa; Przyb. 13/83 konspekty, rękopisy.

127 H. Barycz, Stanisław Kot-życie i dzieło..., s. 18.

128 J. Draus, op. cit., s. 337; T.P. Rutkowski, Stanisław Kot..., s. 22. 


\section{Niezrealizowane plany dodatkowych studiów}

Na próbę podjęcia przez Stanisława Kota studiów prawniczych wskazują już wpisy w katalogach studentów Uniwersytetu Lwowskiego za semestr zimowy roku akademickiego 1907/1908 ${ }^{129}$. Przy jego nazwisku widnieją wówczas, jednak później skreślone, takie zajęcia jak: „Historia instytucji prawa rzymskiego”, „Historia źródeł i prawa publicznego niemieckiego” oraz „Historia ustroju Polski” (te zajęcia z podaniem osoby prowadzącego Oswalda Balzera ${ }^{130}$ ). Jedynie w semestrze letnim uczęszczał wówczas na zajęcia z administracji państwa rzymskiego ${ }^{131}$.

Do koncepcji studiów prawniczych powrócił jednak już na początku kolejnego roku akademickiego. W wydanym wówczas indeksie S. Kota odnajdujemy, obok wspominanych już wcześniej seminariów Bruchnalskiego, Kallenbacha, Finkla oraz Sinki, przede wszystkim przedmioty ściśle związane z nowym kierunkiem studiów. Kot uczęszczał wówczas m.in. na zajęcia Oswalda Balzera ( $\mathrm{z}$ „Historii ustroju Polski” oraz „Historii ustroju Austrii”), Marcelego Chlamtacza ${ }^{132}$, Władysława Abrahamaa ${ }^{133}$ i Józefa Buzka ${ }^{134}$. Jednak najwyraźniej pragnął łączyć edukację prawniczą z dalszym rozwijaniem swoich zainteresowań humanistycznych. Świadczą o tym wymownie wpisane do jego indeksu, z czasem jednak skreślone i niepotwierdzone podpisem prowadzących, zajęcia z zakresu filologii polskiej (m.in. kontynuacja seminarium historii literatury polskiej Bruchnalskiego i seminarium polonistycznego Kallenbacha), historii (seminarium historyczne Finkla) czy filozofii i psychologii (wykłady z filozofii epoki odrodzenia oraz zajęcia z zakresu psychologii myślenia u Twardowskiego) ${ }^{135}$. Po czterech semestrach porzucił jednak ostatecznie studia prawnicze.

Zachowana dokumentacja dotycząca uniwersyteckiego okresu życia Stanisława Kota świadczy wymownie o jego szerokich i ambitnych planach edukacyjnych, które nie zawsze był on w stanie realizować. Dotyczy to nie tylko jego studiów na Wydziale Prawa, ale także na Wydziale Filozoficznym. Przykładowo w roku akademickim 1907/1908 za-

129 DALO, f. 26, op. 15, spr. 618.

${ }^{130}$ Oswald Marian Balzer (1858-1933) historyk prawa i ustroju dawnej Polski, wieloletni profesor Uniwersytetu Lwowskiego. Por. M. Wierzbicka, Balzer Marian, w: Słownik historyków polskich..., s. 26-27; A. Wierzbicki, Oswald Balzer (1858-1933), w: Zlota księga historiografii lwowskiej..., s. 255-268.

131 DALO, f. 26, op. 15, spr. 617.

132 Marceli Chlamtacz (1865-1947), docent i kierownik Katedry Prawa Rzymskiego Uniwersytetu Lwowskiego, wykładał na tej uczelni prawo rzymskie w latach 1898-1935. W roku akad. 1905/1906 był dziekanem Wydziału Prawa. Por. Biogramy uczonych polskich...., cz. I, z. 1, s. 189-190.

133 Władysław Henryk Franciszek Abraham (1860-1941), docent prawa kościelnego na Uniwersytecie Jagiellońskim, następnie profesor Uniwersytetu Lwowskiego, kierownik Katedry Prawa kanonicznego i dziekan Wydziału Prawa oraz rektor tej uczelni. Por. Biogramy uczonych polskich...., cz. I, z. 1, s. 22-26.

134 Józef Buzek (1873-1936), historyk, prawnik i ekonomista, po roku 1904 profesor prawa administracyjnego i statystki na Uniwersytecie we Lwowie. Założył, a później przez wiele lat kierował Głównym Urzędem Statystycznym. Autor wielu prac historycznych w tym m.in. Rozwój stanu szkół średnich w Galicji w ciagu ostatnich 50 lat, Lwów 1909. Por. H. Winnicka, Józef Buzek, w: Stownik historyków polskich..., s. 67-68.

135 AUJ, Spuścizna Stanisława Kota..., sygn. 70/1..., Indeks S. Kota. 
mierzał uczestniczyć w zajęciach Wiktora Hahna ${ }^{136}$ obejmujących problematykę hellenizmu w Polsce oraz poezji hellenistycznej, a także słuchać wykładu B. Dembińskiego zatytułowanego „Machiavelli i jego wiek”137. Jednak najwyraźniej później zmienił plany i ostatecznie nie brał udziału w tych wykładach i ćwiczeniach.

W roku akademickim 1906/1907 w planie jego studiów odnajdujemy najwięcej skreślonych przedmiotów, co szczególnie interesujące - niektóre z nich są dość osobliwe. O ile zdziwienia nie budzi chęć uczestnictwa w ćwiczeniach i wykładach dotyczących uniwersytetów w Polsce, w zajęciach filozoficznych Witolda Rubczyńskiego ${ }^{138}$, czy studiowanie logiki i metod badań naukowych u Twardowskiego, o tyle zastanawiają zamiary zgłębiania dziejów starożytnego malarstwa, historii gramatyki języka serbsko-bułgarskiego, a przede wszystkim higieny żywienia ${ }^{139}$.

\section{Doktorat Stanisława Kota}

Zwieńczeniem lwowskich studiów Stanisława Kota było uzyskanie przez niego w roku 1909 na tamtejszej uczelni stopnia doktora filozofii. Jako swoją rozprawę doktorską przedstawił, liczącą 210 stron pracę pt. „Wpływ starożytności klasycznej na rozwój pojęć politycznych w Polsce w XVI wieku, a w szczególności na Andrzeja Frycza z Modrzewa"140. Recenzentami w tym przewodzie wyznaczeni zostali jego Mistrzowie z okresu studiów W. Bruchnalski i J. Kallenbach. W Księdze protokołów egzaminów doktorskich lwowskiej uczelni z tego okresu odnajdujemy tylko jedną recenzję tej rozprawy, autorstwa Bruchnalskiego. Kallenbach zamieścił pod nią jedynie lakoniczną adnotację: Zgadzam się z powyższymi wywodami z pewnemi zastrzeżeniami, które osobno umotywuję ${ }^{141}$.

W związku z tym, że dotychczas w literaturze nie prezentowano szerzej okoliczności uzyskania przez Kota doktoratu i nie powoływano się na recenzje dysertacji kwestiom tym należy poświecić nieco więcej uwagi. Jego niezwykle pozytywnie oceniona rozprawa składała się z dwóch części. Pierwsza, 60-stronnicowa, dotyczyła „Wpływu starożytności klasycznej na rozwój pojęć patriotycznych w Polsce w XVI w.” w drugiej natomiast autor szeroko wyjaśniał na 120 stronach, „Wpływ starożytności klasycznej na teorie polityczne

136 Wiktor Hahn (1871-1959), historyk literatury, bibliograf, w latach 1907-1918 związany z Katedrą Historii Literatury Polskiej Uniwersytetu Lwowskiego. Por. J. Starnawski, Wiktor Hahn, w: idem, Sylwetki lwowskich historyków..., s. 109-119; A. Wałęga, Hahn Wiktor, w: Słownik biograficzny polskiej historii wychowania..., s. 271-276.

137 DALO, f. 26, op. 15, spr. 618.

138 Witold Rubczyński (1864-1938), od roku 1902 docent historii filozofii Uniwersytetu Lwowskiego, w latach 1910 - 1931 związany z Uniwersytetem Jagiellońskim. Por. U. Perkowska, Corpus Academicorum Facultatis Philosophiae Universitatis Iagellonicae 1850-1945, Kraków 2007, s. 315-316; W. Szulakiewicz, W cieniu filozofi. Witolda Rubczyńskiego idee pedagogiki osobowości, w: Myśl pedagogiczna przełomu wieków, red. T. Aleksander, Kraków 2001, s. 43-55.

139 DALO, f. 26, op.15, spr. 615-616.

140 Ibidem, spr. 726, Księga protokołów o złożenie egzaminów końcowych na dysertację doktorską, k. 305 .

141 Jak wynika z całościowej analizy zawartości tej księgi, była to wówczas dość często stosowana praktyka. 
Andrzeja Frycza z Modrzewa". Warto spytać o to, jakie czynniki wpłynęły na tak przychylną ocenę recenzenta? W. Bruchnalski zwrócił uwagę przede wszystkim na oryginalność podejmowanych badań. Podkreślił bowiem, że Rzecz cała z powodu zupełnego niemal braku podobnych opracowań w historyczno-krytycznej literaturze polskiej, oparta została na studiach samodzielnych. Pozytywnie ocenił zarówno logiczny układ treści, trafność sądów wyrażanych przez Kota, jak i ukazywanie omawianych zjawisk na szerszym tle. Biorąc pod uwagę pozycję, którą zajmował recenzent w ówczesnym środowisku naukowym warto przytoczyć fragment jego opinii: Autor, na czele oceniwszy bardzo trafnie a przytem jędrnie z jednej strony „Naprawę Rzeczypospolitej” jako książę w swoim rodzaju jedyna, bo ujmująca całość życia państwowego w system jednolity - z drugiej zaś jej twórce jako autora, który organizacja indywidualna odbija mocno od innych nawet większych i bardziej od niego znanych polityków zagranicznych, przez to, że w dziele swojem jedynie i najlepiej (epokę pod uwage biorac) potrafit złaczyć szeroka abstrakcyjna wiedze ze zmystem praktycznym i przeżyciami rzeczywistymi-przechodzi nastepnie a logicznie do kwestii, jaki byt podkład teoretyczny, tak projektów jak i reform politycznych Frycza i analitycznie rozwija ją w następnych częściach swej pracy ${ }^{142}$.

Za słuszne uznał recenzent, przyjęte przez Kota, założenie dotyczące wysokiego poziomu starożytnych pism politycznych i ich oddziaływania na późniejszych autorów, w szczególności tych, którzy w wieku XVI pozostawali pod intensywnym wpływem prądów humanistycznych. Ukazanie klasycznych źródeł inspiracji Modrzewskiego, czyli Arystotelesa, Cycerona oraz Platona, pozwoliło zdaniem Bruchnalskiego nie tylko wydać właściwą opinię na temat traktatu O poprawie Rzeczypospolitej..., lecz także wszechstronnie ją uzasadnić. Zwrócił on także uwagę na zamieszczoną w pracy charakterystykę polskiej kultury politycznej XVI w., która stanowiła doskonały punkt wyjścia dla podejmowanych w niej analiz porównawczych. W ocenie Bruchnalskiego to właśnie Kot ukazał w swojej rozprawie doktorskiej najobszerniej, najwszechstronniej i najgruntowniej zjawisko wpływu wzorców klasycznych na styl życia Polaków w epoce renesansu. Wyraźnie podkreślił też jego znaczący i oryginalny wkład do badań nad tą problematyką. Swoją opinię uzasadniał następująco: Jego (czyli S. Kota-A.W.) własnościa przeważnie, bądź nawet $w$ zupetności pozostanie mianowicie jasno określone stwierdzenie wpływu teorii starożytnych, na tworzenie się politycznych i społecznych pojęć polskiego ogółu szlacheckiego, tak dawniejszego jak i współczesnego Modrzewskiemu - następnie wyszukanie kilku nader ciekawych analogii między polityczna myśla świata starożytnego a szlachecko-polskiego (terminologia praktyczna, pesymizm polityczny, doskonałość przodków, zachwycanie się przeszłościa itp. $)^{143}$.

Odnosząc się do ostatniej i najobszerniejszej części pracy, poświęconej wyłącznie analizie dzieła Frycza, uznał, że mogła ona być bardziej rozbudowana i przede wszystkim podzielona na mniejsze podrozdziały. Docenił jednak bogactwo zawartych tam treści oraz logiczny plan prezentowania poszczególnych zagadnień. Kot ukazał w niej bowiem zarówno charakter i cel dzieła, jak i metodę oraz główne pojęcia polityczne i idee Modrzew-

${ }^{142}$ DALO, f. 26, op. 15 , spr. 726, k. 305.

143 Ibidem. 
skiego, ze szczególnym uwzględnieniem tych, których źródła tkwią w starożytności. Chociaż recenzent dostrzegł pewną nierównomierność w opracowaniu niektórych problemów oraz widoczny wyraźnie, szczególnie w partiach końcowych rozprawy, pośpiech autora, to ostatecznie wystawił mu ocenę niezwykle pozytywną. Jak stwierdzał Bruchnalski w podsumowaniu swojej opinii: biorac rzecz sumarycznie - trzeba przyznać, że autor doszedt do wyników ciekawych, wartościowych i nowych, by dla przykładu przytoczyć tylko charakterystykę pracy Modrzewskiego lub bardzo dokładny a $w$ ten sposób po raz pierwszy wykonany rozbiór jego idei i pomysłów, z odniesieniem ich do Arystotelesa, Platona czy Cicerona i roztrzaśnięciem prawie zawsze dodanem, dlaczego w pewnej chwili jedno źródło brało górę nad drugiemi itp. ${ }^{144}$

Po uzyskaniu tak pozytywnej recenzji S. Kot przystąpił do egzaminów doktorskich. W dniu 21 czerwca 1909 r., po dwugodzinnym egzaminie ścisłym z filologii polskiej i historii polskiej, otrzymał cztery oceny celujące. W Komisji egzaminacyjnej oprócz Bruchnalskiego i Kallenbacha zasiadali także dwaj inni jego profesorowie Zakrzewski i Witkowski.Znakomity wynik egzaminów oraz pozytywne przyjęcie rozprawy o Modrzewskim, która wkrótce ukazała się drukiem, umożliwiły przyszłemu autorowi Historii wychowania szybką akceptację ze strony środowiska naukowego Krakowa. Fascynacja dziełem O poprawie Rzeczypospolitej zaowocowała też w przyszłości kolejnymi rozprawami naukowymi. Jedna z nich stanowiła podstawę habilitacji Kota na Uniwersytecie Jagiellońskim.

\section{Uwagi końcowe}

Studencki okres życia Stanisława Kota to czas niezwykle intensywnego i wielostronnego rozwoju intelektualnego krakowskiego historyka kultury. Jego lwowskie studia trwały łącznie 12 semestrów, z czego pierwszych osiem spędził głównie na Wydziale Filozoficznym, a ostatnie cztery na Wydziale Prawa. Należy jednak podkreślić, że kontakty ze swoimi wykładowcami z zakresu historii literatury Wilhelmem Bruchnalskim i Józefem Kallenbachem starał się podtrzymywać do końca swoich studiów. Uwzględniając ich regularne i częste, a trwające 6 lat, w tym 4 lata w ramach seminariów, spotkania - można wysnuć wniosek o ich znaczącym wpływie na młodego i zdolnego studenta. W późniejszym okresie do grona jego potencjalnych Mistrzów dołączyli historyk Ludwik Finkel oraz pedagog Bolesław Mańkowski. Ich zainteresowania historią oświaty i historią kultury w znacznym stopniu mogły wpłynąć na ukierunkowanie przyszłych badań Kota. To we Lwowie zdobył oprócz doktoratu także solidne podstawy dla swojej dalszej pracy naukowej i dydaktycznej. Miał ją już jednak prowadzić w Krakowie, mieście, które - gdy tuż po maturze podejmował decyzję o wyborze uczelni - wydawało mu się zaśniedziałym, konserwatywnym, ugodowym [...], klerykalnym ${ }^{145}$.

\footnotetext{
144 Ibidem.

145 S. Kot, Stanisław Estreicher..., s. 3-4, cyt. za T.P. Rutkowski, Stanisław Kot 1885-1975..., s. 15.
} 


\title{
Stanisław Kot's research and study in Lvov \\ - on the way to earning his doctorate degree
}

\begin{abstract}
Summary
Stanisław Kot, one of the creators of the history of education as a scientific discipline, studied at the University of Lvov between 1904 and 1909. His special line was classical philology, Polish philology and, for two terms, legal studies. The hitherto written relevant historical and educational literature does not address these issues in detail - Kot's professional life in Cracow is far better known and elaborated. However, on the basis of the analysis of the Lvov archival material from the State District Archive in Lvov (primarily student catalogues and examination protocols for doctoral examinations), it is possible to reconstruct the course of studies of this well-known historian of education until the very last stage of his doctoral achievements, i.e. his successful defense of his dissertation in 1909. The scope of this study was fairly wide. The comprehensive and extensive knowledge in the history of literature, both Polish and general, history, pedagogy, philosophy and psychology that he gained in Lvov, as well as the excellent knowledge of the Polish language and classical languages, formed a firm base for Kot to pursue professional career on his own. It was the Lvov scholarly environment that shaped him as a researcher and scholar and made it possible for him to not only debut as a scholar but also to encounter and come into contact with scholars from the academic centers of Cracow. Thanks to his brilliantly-written doctoral dissertation, supervised by Wilhelm Bruchnalski and Józef Kallenbach from Lvov, and to his first publications in the periodical "Muzeum" (which he presented at a pedagogical seminar prepared by Bolesław Mańkowski), S. Kot quickly gained a reputation as a precise scholar among the university circles of the town. Also in the later period of his professional career he remained in close contact with his former university lecturers and cooperated with them, for example, on the work on the successive volumes of the publication of book series Biblioteka Narodowa (National Library).
\end{abstract}

